\title{
Estimasi Daya Dukung Sumber Daya Air di Pulau Kecil (Studi Kasus Pulau Pari)
}

\section{Dyah Marganingrum ${ }^{1}$}

Pusat Penelitian Geoteknologi, Lembaga IImu Pengetahuan Indonesia (LIPI), Indonesia

\author{
Yayat Sudrajat \\ Pusat Penelitian Geoteknologi, Lembaga IImu Pengetahuan Indonesia (LIPI), Indonesia
}

Artikel Masuk : 9 April 2018

Artikel Diterima : 30 Agustus 2018

Tersedia Online : 31 Desember 2018

\begin{abstract}
Abstrak: Pulau kecil memiliki keterbatasan dalam penyediaan sumber daya air tawar karena kapasitas penyimpanannya terbatas. Di satu sisi pulau-pulau kecil sering kali dijadikan sebagai tujuan wisata. Dalam konteks ini perlu dilakukan upaya agar sumber daya air tawar di pulau kecil dapat berkelanjutan untuk mendukung tujuan wisata tersebut. Penelitian ini bertujuan untuk melakukan estimasi perhitungan daya dukung sumber daya air tawar di Pulau Pari. Metode estimasi dilakukan dengan memperhatikan luas pulau, ketebalan akuifer, curah hujan tahunan, konduktivitas hidraulis atau permeabilitas tanah, dan aplikasi teknologi pemanenan air hujan (PAH). Hasil estimasi daya dukung sumber daya air tawar Pulau Pari untuk kondisi eksisting tanpa intervensi teknologi adalah aman dengan nilai rasio ketersediaan terhadap kebutuhan sebesar 2,05. Namun kondisi ini belum memperhatikan aspek kualitas. Aspek kualitas dapat ditingkatkan dengan mengaplikasikan teknologi PAH, namun menghasilkan status daya dukung sumber daya air tawar sebesar 1,34 dan 1,47 (aman bersyarat) masing-masing untuk kondisi eksisting dan prediksi 25 tahun ke depan. Berdasarkan hasil perhitungan studi ini, rekomendasi yang diberikan adalah perlu segera melakukan pengelolaan di sektor pariwisata, terutama pengaturan jumlah pengunjung wisata, agar ketersediaan air di Pulau Pari dapat berkelanjutan dan tidak berdampak pada kelangsungan hidup masyarakat yang tinggal di Pulau Pari dan ekosistem Pulau Pari sendiri.
\end{abstract}

Kata Kunci: keberlanjutan; pemanenan air hujan (PAH); pariwisata

\begin{abstract}
Small islands are often promoted as a tourism destination in spite of the limited fresh water resources availability that they could retain for daily needs. In this context, efforts to provide fresh water resources sustainable in the small island are necessary to support the tourism destination purpose. This study aims to estimate the carrying capacity of the fresh water resources in Pari Island. The estimation method is the ratio between the fresh water availability and its demand by calculating the island size, aquifer thickness, annual rainfall, hydraulic conductivity or soil permeability, and the application of rainwater harvesting technology (RHT). The result shows that the carrying capacity of the fresh water resources without technological intervention in Pari Island is 2.05. Even though this score indicates the safe level, the measure has not taken the water quality into consideration yet. Expectedly, it could be improved by applying the RHT technology but it results in the carrying capacity score of 1.37 and 1.47 (conditionally safe) for the current state and 25-year future prediction
\end{abstract}

\footnotetext{
${ }^{1}$ Korespondensi Penulis: Pusat Penelitian Geoteknologi, Lembaga Ilmu Pengetahuan Indonesia (LIPI), Indonesia email: dmarganingrum@yahoo.com
} 
respectively. This study recommends the improvements in tourism management by limiting the visitor number in order to support their sustainability for the local livelihood and Pari Island's ecosystem conservation.

Keywords: rainwater harvesting; sustainability; tourism

\section{Pendahuluan}

Berdasarkan Undang-Undang Nomor 1 Tahun 2014 tentang Perubahan atas UndangUndang Nomor 27 Tahun 2007 tentang Pengelolaan Wilayah Pesisir dan Pulau-Pulau Kecil, definisi pulau kecil adalah pulau dengan luas lebih kecil atau sama dengan $2000 \mathrm{~km}^{2}$ beserta kesatuan ekosistemnya. Merujuk hasil perhitungan luasan pulau di seluruh dunia yang tertuang dalam Island Dictionary, pulau-pulau di Indonesia dengan luas lebih dari $2000 \mathrm{~km}^{2}$ hanya sebanyak 28 pulau (UNEP, 2014). Sementara data dari Kementerian Kelautan dan Perikanan menyebutkan bahwa jumlah pulau di seluruh nusantara sebanyak 17.408 pulau (Hidayah, Rosyid, \& Dwito, 2016). Dengan demikian, terdapat lebih dari 17 ribu pulau di Indonesia berkategori sebagai pulau kecil. Kenyataan ini menjadi potensi sekaligus tantangan yang sangat besar dalam upaya pengelolaannya.

Kebijakan pemerintah yang menjadikan pulau-pulau kecil di Indonesia sebagai salah satu tujuan wisata berimplikasi terhadap peningkatan kebutuhan air tawar yang sesuai dengan peruntukannya (fresh water). Sumber air tawar di pulau-pulau kecil sepenuhnya berasal dari air hujan atau air meteorik karena wilayah tangkapan yang terbatas, sehingga kapasitas atau daya tampung pulau-pulau kecil dalam penyimpanan air hujan juga sangat terbatas. Isu perubahan iklim dan peningkatan muka air laut semakin mengancam keberadaan sumber daya air tawar di pulau-pulau kecil (Masterson et al., 2013; Rasmussen, Sonnenborg, Goncear, \& Hinsby, 2013; White et al., 2007). Oleh karena itu, pengelolaan sumber daya air tawar di pulau-pulau kecil Indonesia menjadi suatu keharusan. Langkah awal dalam melakukan pengelolaan sumber daya air tawar di pulau-pulau kecil dapat ditempuh dengan melakukan estimasi daya dukung sumber daya air tawar yang ada di pulau kecil tersebut. Estimasi ini perlu dilakukan untuk mengatur pola pemanfaatan dan konservasinya agar keberlanjutan sumber daya airnya dapat berkelanjutan.

Estimasi daya dukung dilakukan pada tataran aspek ketersediaan dan aspek kebutuhan. Pada aspek ketersediaan, dua hal yang perlu dipertimbangkan yaitu support capacity dan assimilative capacity atau faktor kuantitas dan kualitas sumber daya air. Hal ini diperlukan untuk mengetahui sejumlah air yang memang dapat dipergunakan untuk memenuhi kebutuhan sesuai standar peruntukannya, baik dari segi jumlah maupun kualitasnya. Jumlah ketersediaan air kemudian dibandingkan dengan kebutuhan di wilayah tersebut untuk mengetahui status daya dukung sumber daya airnya (Kartodihardjo, 2011; Marganingrum, 2013, 2018). Langkah ini diperlukan untuk memberikan informasi bagi pengambil kebijakan dalam pengelolaan sumber daya air di suatu wilayah secara berkelanjutan. Penelitian ini membatasi daya dukung sumber daya air pada tataran konsep support capacity karena masih terbatas pada estimasi potensi sumber daya air. Meski tidak dimasukkan dalam perhitungan, hasil analisis pemantauan kualitas air di lokasi studi akan disampaikan dalam makalah ini.

Untuk mengestimasi potensi ketersediaan sumber daya air di pulau kecil, maka beberapa variabel perlu diidentifikasi dan diketahui. Beberapa model telah dikembangkan untuk mengestimasi ketebalan lensa air di pulau-pulau kecil, baik model analitis maupun empiris. Bailey, Jenson, \& Olsen (2010) mengkaji beberapa model yang sudah dipublikasikan menggunakan model aljabar sederhana. Menurut Bailey et al. (2010), modelmodel tersebut belum sepenuhnya menggabungkan karakteristik unik geologi pulau atol dan belum mempertimbangkan variabel waktu dalam model (Bailey et al., 2010). Oleh 
karena itu, Bailey et al. (2010) memberikan perkiraan ketebalan lensa air tawar sebagai fungsi dari tingkat curah hujan tahunan, luas pulau, kedalaman akuifer, konduktivitas hidraulis akuifer, ada tidaknya lempeng datar terumbu, dan ada tidaknya kasus kekeringan, serta variabel waktu.

Selanjutnya Bailey, Khalil, \& Chatikavanij (2014) kembali melakukan estimasi ketebalan dan volume lensa air di enam pulau kecil di wilayah Republik Maldives menggunakan pemodelan. Variabel yang digunakan adalah rata-rata hujan tahunan (m/tahun), lebar pulau (m), laju infiltrasi ke dalam akuifer-K (m/day), dan kedalaman akuifer (m) yang merupakan batas perubahan tebal lensa air tawar (Bailey et al., 2015). Variabel-variabel input lensa air sebagaimana telah disebutkan adalah untuk mengetahui ketersediaan air di pulau kecil. Perhitungan ketersediaan air umumnya menggunakan pendekatan neraca air (water balance) (Tatas, Budipriyanto, Khoiri, Lestari, \& Rahman, 2015). Selain input air yang masuk (recharge), kehilangan air karena evapotranspirasi, runoff, dan pengambilan air tanah oleh masyarakat juga perlu dihitung untuk mengetahui keseimbangan airnya (Bailey et al., 2014; Post, Bosserelle, Galvis, Sinclair, \& Werner, 2018). Dengan mengetahui ketersediaan dan pemanfaatan sumber daya air, maka dapat dilakukan pola pengelolaan sumber daya air agar tercapai status daya dukung sumber daya air yang berkelanjutan.

Penelitian ini bertujuan menghitung daya dukung sumber daya air di Pulau Pari. Perhitungan daya dukung dilakukan dengan mengestimasi potensi ketersediaan air tawar di Pulau Pari. Estimasi dilakukan dengan pendekatan kapasitas maksimum penyimpanan air dalam bentuk air tanah secara alami ataupun air tampungan (surface water) melalui teknologi Pemanenan Air Hujan (PAH). Estimasi tersebut kemudian dibandingkan dengan kondisi eksisting penggunaan air serta prediksi keseimbangan sumber daya air di masa depan. Hasil perhitungan tersebut diharapkan dapat menjadi masukan bagi pengambil kebijakan dalam mengatur pola penggunaan air sekaligus mengendalikan kegiatan atau aktivitas yang memerlukan ketersediaan air di Pulau Pari.

\section{Metode Penelitian}

\section{Lokasi Studi}

Penelitian ini dilakukan di Pulau Pari yang merupakan salah satu dari 110 pulau karang (koral) dan merupakan pulau terbesar dari pulau-pulau penyusun gugusan Pulau Pari yang terdapat di Kabupaten Kepulauan Seribu, yang secara administratif merupakan bagian dari wilayah pemerintahan Provinsi Daerah Khusus Ibukota (DKI) Jakarta (Gambar 1). Secara geografis, Pulau Pari terletak pada $5^{\circ} 52^{\prime} 50^{\prime \prime}-5^{\circ} 54^{\prime} 50^{\prime \prime}$ Lintang Selatan dan $106^{\circ} 34^{\prime} 00^{\prime \prime}-106^{\circ} 38^{\prime} 00^{\prime \prime}$ Bujur Timur dengan luas 41,32 ha (Narulita, Santoso, Hantoro, \& Djuwansah, 2005). Dengan luasan tersebut, Pulau Pari tergolong sebagai pulau sangat kecil (tiny islands). Definisi tiny island adalah pulau kecil dengan luas area kurang dari $100 \mathrm{~km}^{2}$ dan lebar kurang dari 3 km (Falkland, 1992). Seperti pulau kecil lainnya, Pulau Pari juga memiliki keterbatasan terkait dengan sumber daya air dikarenakan daya tangkapan airnya yang terbatas serta ancaman intrusi air laut dan pencemaran (Suparyanto, 2005).

Sebagai pulau karang timbul, yang penampakannya apabila dilihat dari citra satelit berbentuk menyerupai ikan pari, Pulau Pari memiliki karakteristik yang unik dari perspektif geologi dan hidrologi. Seperti halnya karakteristik pulau atol lainnya, Pulau Pari juga memiliki elevasi antara 0-3 meter di atas permukaan laut dengan lebar pulau tidak lebih dari $500 \mathrm{~m}$. Dengan elevasi yang rendah, luas permukaan yang terbatas, berdekatan dengan Ibukota Indonesia (Jakarta) menyebabkan Pulau Pari rentan terhadap eksploitasi dan kekeringan. Kerentanan tersebut semakin meningkat karena Pulau Pari sesuai dengan Perda DKI Jakarta Nomor 1 Tahun 2012 telah ditetapkan sebagai salah satu kawasan 
wisata yang berwawasan ilmu pengetahuan (Aunillah dkk., 2014; Bailey et al., 2010; Utomo et al., 2015).

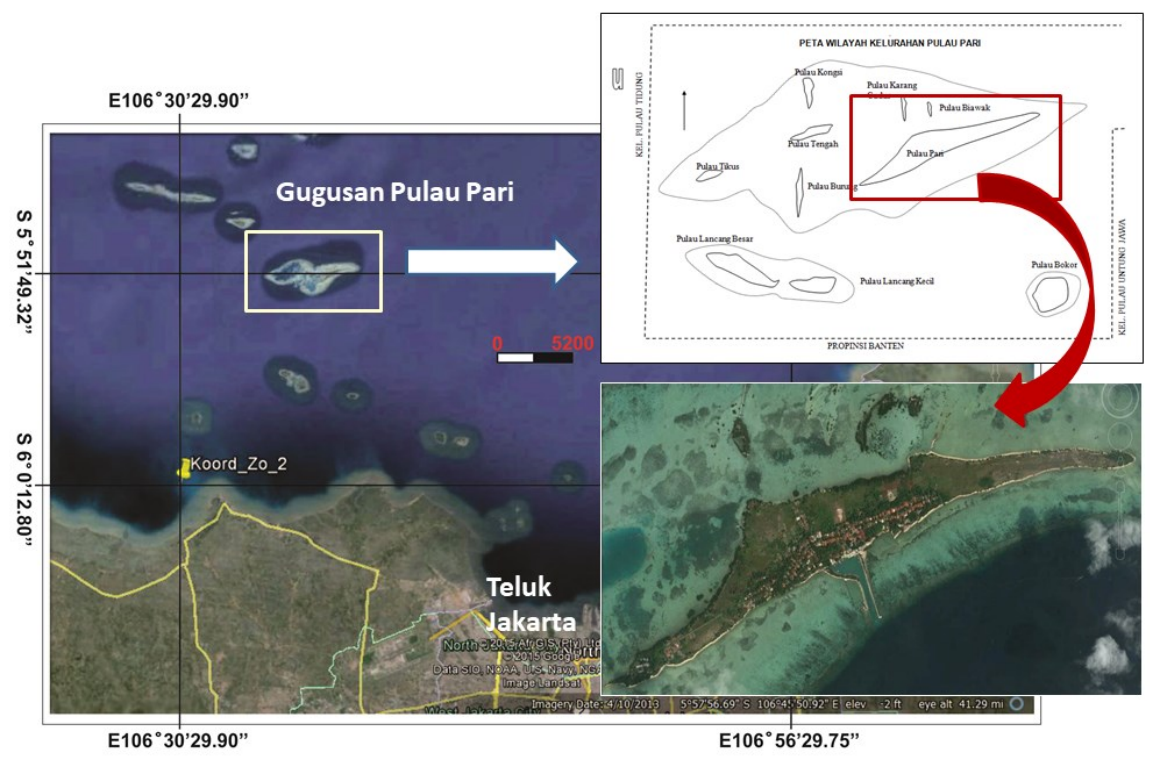

Gambar 1. Lokasi Studi (Pulau Pari)

\section{Metode Analisis Data}

Metode pendekatan yang digunakan dalam penelitian ini adalah konsep daya dukung sumber daya air. Daya dukung yang dimaksud adalah support capacity atau ketersediaan air yang memenuhi kebutuhan (Kartodihardjo, 2011). Oleh karena itu, perlu dihitung jumlah ketersediaan air dan kebutuhan air yang diperlukan di Pulau Pari. Persamaan empiris digunakan untuk mengestimasi potensi jumlah atau volume ketersediaan air tawar. Sementara jumlah kebutuhan eksisting diperkirakan melalui jumlah penduduk dan wisatawan dikalikan dengan kebutuhan minimal sesuai dengan kriteria World Health Organization (WHO) yaitu sebesar 60 liter/orang/hari $\left(21,9 \mathrm{~m}^{3} /\right.$ orang/tahun) sebagai kebutuhan dasar.

Mengingat daya tangkapan air (catchment area) pulau yang kecil, maka diasumsikan bahwa air hujan dapat ditangkap dengan memanfaatkan atap rumah atau gedung dan menyimpannya. Ini dilakukan dengan asumsi bahwa teknologi rainwater harvesting atau PAH diterapkan di Pulau Pari. Potensi air hujan yang dapat ditangkap (HW) dihitung menggunakan persamaan empiris sebagaimana persamaan (1) (Traboulsi \& Traboulsi, 2017).

$$
\mathrm{HW}=\mathrm{R} \times \mathrm{A} \times \mathrm{K}
$$

Keterangan:

$\mathrm{HW}=$ harvested water (jumlah air yang dapat disimpan)

$\mathrm{R} \quad=$ hujan rata-rata di daerah studi

$\mathrm{A}=$ total luas atap

$\mathrm{K}=$ koefisien run-off $=80 \%$ (asumsi kehilangan air sebesar $20 \%$ melalui pembersihan atap dan evaporasi)

Sementara daya tangkap pulau secara alami diperkirakan dengan cara menghitung potensi volume lensa air yang ada di Pulau Pari yang dapat berfungsi sebagai penyimpan 
air hujan sebagaimana yang dirumuskan oleh Bailey et al., (2010) dengan modifikasi sebagaimana persamaan (2).

Volume Lensa Air $(\mathrm{VLa})=f\left(\mathrm{P}, \mathrm{A}, \mathrm{h}, \mathrm{K}_{\mathrm{h}}\right)$ dalam $\mathrm{m}^{3}$

$$
V L a=\frac{P x A x h}{K_{h}}
$$

Keterangan:

$\mathrm{P}=$ hujan tahunan rata-rata $(\mathrm{m} /$ tahun$)$

$\mathrm{A}=$ luas pulau $\left(\mathrm{m}^{2}\right)$

$\mathrm{h}=$ ketebalan atau kedalaman akuifer rata-rata $(\mathrm{m})$

$\mathrm{K}_{\mathrm{h}}=$ konduktifitas hidraulis ( $\left.\mathrm{m} / \mathrm{hari}\right)$

Potensi ketebalan atau kedalaman akuifer ditentukan melalui uji geolistrik. Metode geolistrik yang digunakan adalah cara dipole-dipole menggunakan multi elektroda. Untuk mendapatkan harga tahanan jenis batuan dengan cara menambahkan arus listrik (DC Block) melalui elektroda transmitter C1,C2 ke dalam tanah (Parasnis, 1986), dan mengukur beda potensial melalui elektroda P1-P8 (Gambar 2).

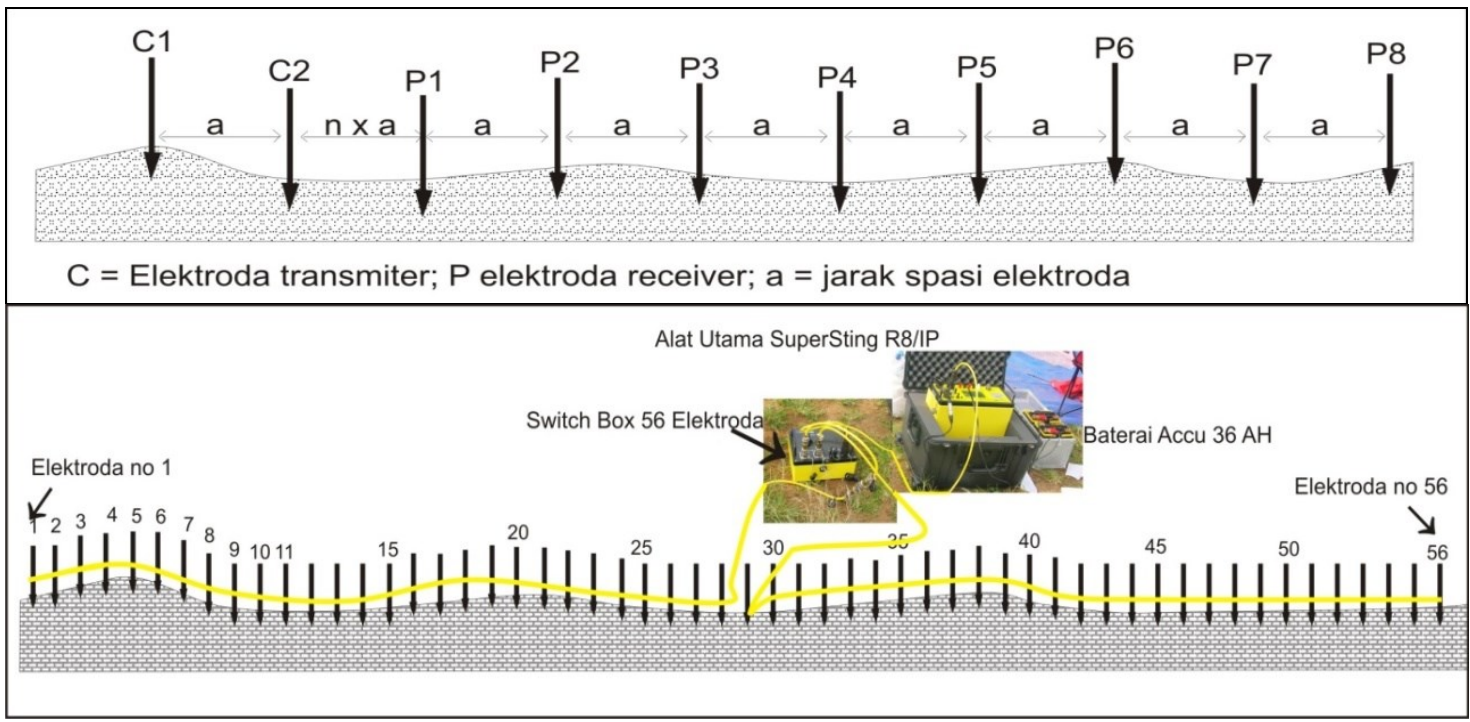

Gambar 2. Sususan Elektroda Dipole dengan 8 Elektroda Penerima P1-P8 yang Diterapkan di Lapangan

Alat yang digunakan dalam pengukuran geolistrik ini adalah SuperSting R8/IP dengan swif elektroda 56 buah, sedangkan pemodelan bawah permukaan dilakukan dengan metode inversi algoritma NLCG (AGI, 2007; Loke, 2006) yang terdapat pada perangkat lunak EarthImager. Pemodelan dilakukan maksimum 10x iterasi. Model selesai jika data misfit $\leq 10 \%$, Rms error $\leq 5 \%$ dan kurva mendekati konvergen. Adapun nilai tahanan jenis untuk beberapa jenis batuan dapat dilihat pada Gambar 3.

Adapun untuk mengetahui konduktivitas hidraulis di lokasi penelitian (Pulau Pari) dilakukan uji akuifer pada tiga titik lokasi. Konduktivitas hidraulis merupakan fungsi laju infiltrasi yang diukur menggunakan double ring infiltrometer dengan ukuran diameter ring luar dan dalam masing-masing adalah kurang lebih $30 \mathrm{~cm}$ dan kurang lebih $15 \mathrm{~cm}$ dengan tinggi ring $20 \mathrm{~cm}$ (Gambar 4). Penggunaan double ring infiltrometer ini mengacu pada hasil 
penelitian (Gregory, Michael, Miller, \& Jones, 2005). Uji akuifer yang dilakukan dalam penelitian ini menggunakan metode constant head dan falling head. Metode constant head mengukur volume air yang ditambahkan untuk menjaga ketinggian air pada ring dalam infiltrometer (inner ring). Sementara metode falling head mengukur waktu untuk mencapai penurunan air pada ketinggian tertentu di dalam inner ring.

Alat infiltrometer dimasukkan ke dalam tanah dengan kedalaman sekitar $10 \mathrm{~cm}$ menggunakan alat pemukul, dengan kedudukan diusahakan tegak lurus serta tanah dalam silinder dijaga jangan sampai rusak atau pecah. Pengisian air dilakukan secara perlahanlahan pada silinder kecil agar tidak merusak struktur permukaan tanah. Pengamatan infiltrasi dilakukan dengan melihat besar penurunan air pada silinder bagian dalam melalui mistar yang sudah terpasang. Apabila ketinggian air pada silinder dalam sudah menurun sampai batas waktu tertentu, maka air harus segera ditambahkan ke dalamnya. Penambahan air terus dilakukan hingga skala penurunan air konstan. Pengukuran waktu pada saat terjadi penurunan ketinggian air dengan menggunakan stopwatch/alat pengukur waktu.

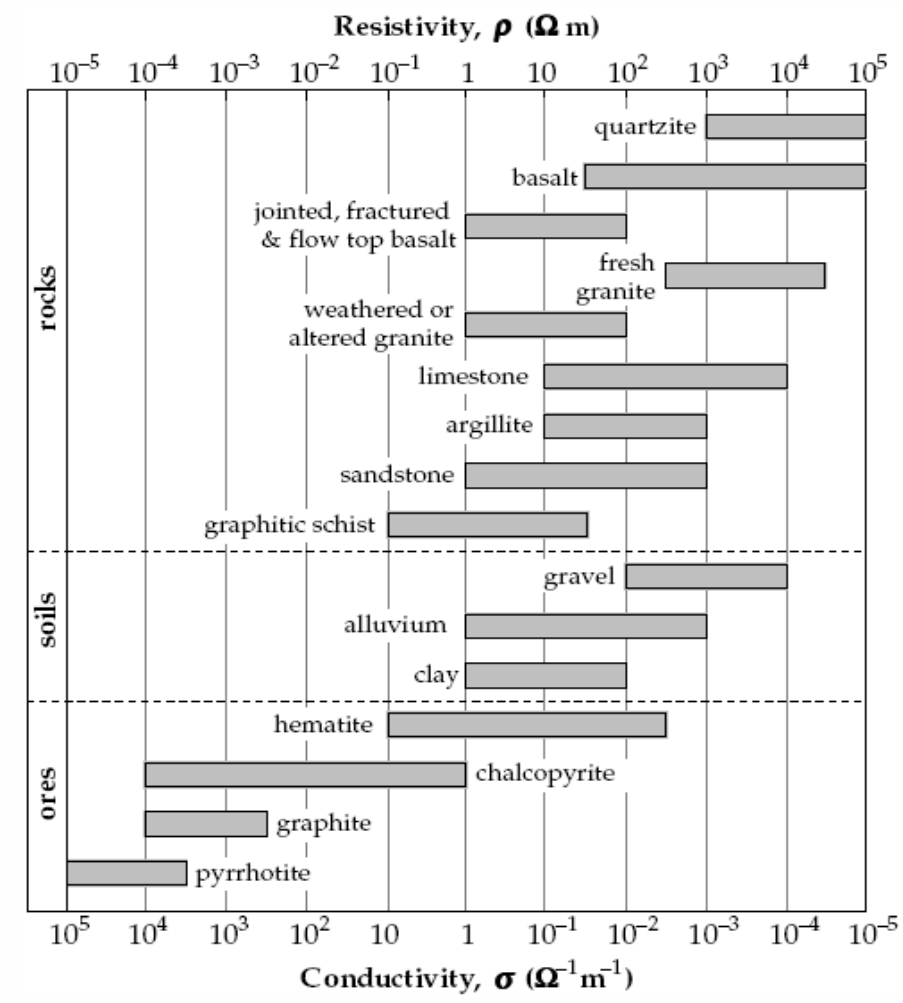

Sumber: Telford, 1990 dalam Utomo, Marganingrum, Sudrajat, Rachmat, \& Ningrum, 2017

\section{Gambar 3. Nilai Kisaran Tahanan Jenis}

Selanjutnya persamaan yang digunakan untuk menghitung konduktivitas hidraulis $\left(\mathrm{K}_{\mathrm{h}}\right)$ dengan pendekatan uji akuifer ini sebagaimana persamaan (3) berikut ini.

$$
\mathbf{K h}=\frac{\text { Volx L }}{\operatorname{Axt\times } \Delta \mathbf{h}}
$$

Keterangan:

$\mathrm{K}_{\mathrm{h}}=$ konduktivitas hidraulis ( $\mathrm{cm} /$ menit)

Vol $=$ volume sumur $\left(\mathrm{cm}^{3}\right)$

$\mathrm{L} \quad=$ kedalaman sumur $(\mathrm{cm})$ 
$\mathrm{A}=$ luas penampang sumur $\left(\mathrm{cm}^{2}\right)$

$\mathrm{t}=$ waktu yang diperlukan untuk mencapai kondisi konstan (menit)

$\Delta \mathrm{h}=$ penurunan muka air tanah $(\mathrm{cm})$

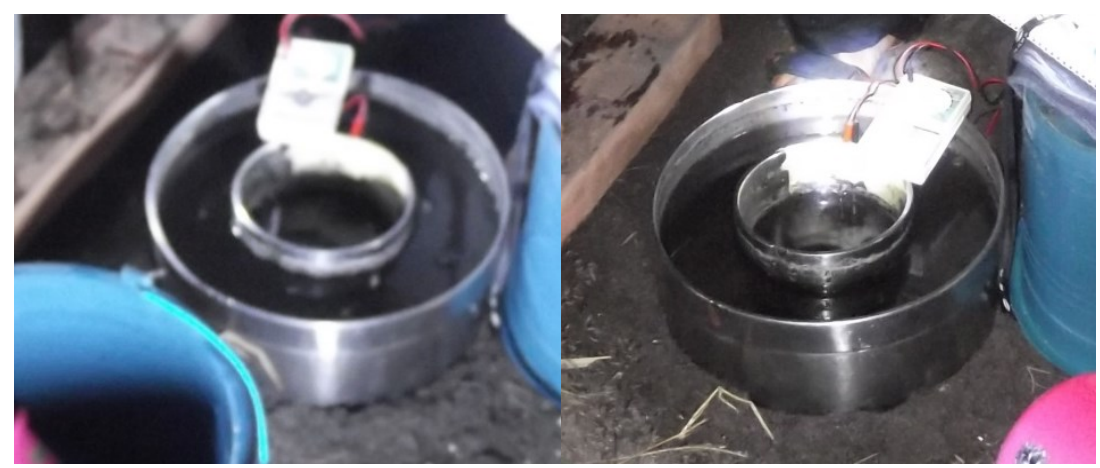

\section{Gambar 4. RingInfiltrometer untuk Mengukur Laju Infiltrasi}

Selanjutnya estimasi perhitungan kebutuhan air dilakukan dengan pendekatan jumlah penduduk yang bermukim di Pulau Pari dan jumlah wisatawan. Status daya dukung sumber daya air di Pulau Pari ditentukan dengan menggunakan rasio antara supply dan demand dengan kriteria penilaian sebagaimana ditunjukkan pada Tabel 1.

Tabel 1. Kriteria Penentuan Status Daya Dukung Lingkungan

\begin{tabular}{ll}
\hline \multicolumn{1}{c}{$\begin{array}{c}\text { Perbandingan } \\
\text { Supply/Demand }\end{array}$} & \multicolumn{1}{c}{ Status Daya Dukung Lingkungan } \\
\hline$>2,0$ & Aman (sustained) \\
$1,0-2,0$ & Aman Bersyarat (conditional sustained) \\
$<1,0$ & Terlampaui (overshoot) \\
\hline Sumber: Kartodihardjo, 2011 &
\end{tabular}

\section{Hasil dan Pembahasan}

\section{Analisis Data Curah Hujan}

Curah hujan merupakan variabel input utama dalam menentukan ketersediaan air di lokasi studi. Data hujan TRMM Pulau Pari tahun 1998 sampai dengan 2015 digunakan untuk analisis ketersediaan air karena data hujan dari hasil pemantauan alat penakar hujan yang dipasang di Pulau Pari mengalami kerusakan setelah tahun 2002. Gambar 5 adalah hasil perhitungan hujan rata-rata bulanan dan akumulasinya, serta nilai evapotranspirasi di Pulau Pari.

Rata-rata hujan bulanan di Pulau Pari menunjukkan pola monsun dengan hujan tertinggi di bulan Februari. Akumulasi hujan rata-rata tahunan di Pulau Pari sebesar 2.219 $\mathrm{mm} /$ tahun. Sebagai lokasi dengan tipe hujan monsun, Pulau Pari tentu akan mendapatkan sumber air baku dalam bentuk air tawar yang potensial untuk memenuhi kebutuhan masyarakat sehari-hari (keperluan rumah tangga). Namun tipe hujan monsun ini juga memiliki tantangan karena adanya fluktuasi yang cukup signifikan antara curah hujan di musim kemarau dan curah hujan di musim hujan. Hasil perhitungan nilai hujan dan evapotranspirasi potensial di Pulau Pari hanya memberikan nilai surplus sebesar $38 \mathrm{~mm}$ per tahun. Oleh karena itu, sudah menjadi keharusan di lokasi seperti ini, air tawar sangat terbatas ketersediaannya untuk melakukan upaya penampungan air hujan agar dapat 


\section{Estimasi Daya Dukung Sumber Daya Air di Pulau Kecil (Studi Kasus Pulau Pari)}

digunakan pada musim kemarau. Namun hasil survei lapangan memperlihatkan bahwa di lokasi studi belum diterapkan teknologi PAH secara menyeluruh. Hanya ada beberapa rumah saja yang telah menerapkan teknologi ini.

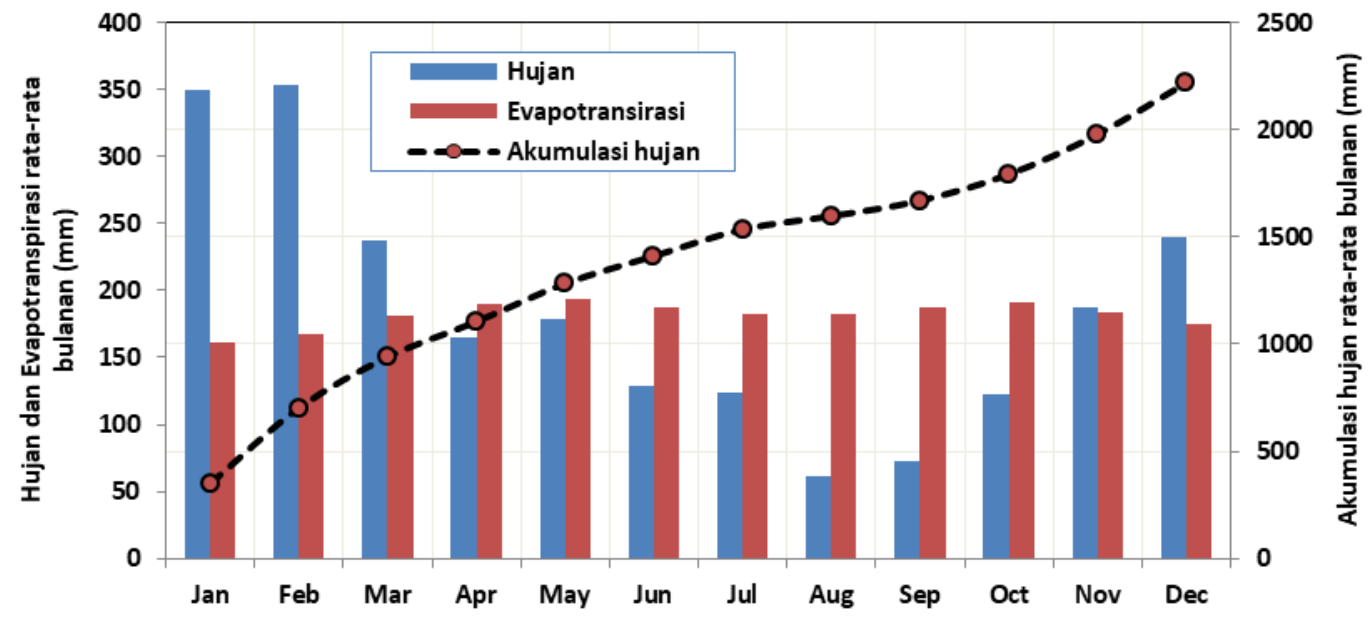

Gambar 5. Curah Hujan dan Evapotranspirasi Rata-Rata Bulanan Pulau Pari

\section{Hasil Pengukuran Geolistrik}

Pengukuran geolistrik dilakukan di beberapa lintasan, yaitu di lokasi kampus UPT LPKSDMO Pulau Pari, lokasi Masjid dan Sumur Sawo, serta secara regional memanjang pulau dan melintang pulau. Air tawar yang ingin didapatkan di lokasi UPT LPKSDMO Pulau Pari cukup sulit sehingga dilakukan pengukuran di sekitar sumur injeksi SIMBAT (Utomo et al., 2017). Pengukuran detail geolistrik di lokasi ini dilakukan dengan multielektroda dengan jarak antarelektroda 1 meter dan kedalaman duga 12 meter. Dari hasil pengukuran geolistrik di lokasi ini diketahui bahwa kedalaman air tawar hanya sekitar 0,8 meter dengan muka air tanah 0,5 m (Gambar 6).

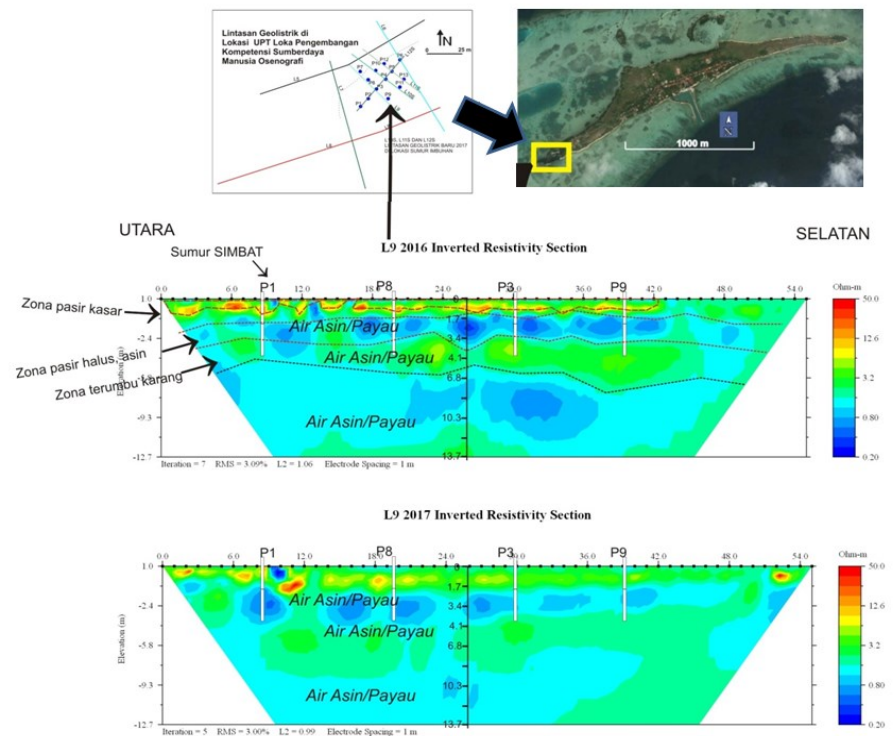

Gambar 6. Penampang Geolistrik L9 di Lokasi Sekitar Sumur Injeksi SIMBAT 
Pengukuran geolistrik selanjutnya dilakukan di sekitar masjid dan Sumur Sawo sebanyak 4 lintasan (lintasan 10,11, 12, dan 13). Lokasi ini merupakan lokasi di tengah Pulau Pari. Potensi air tanah di lokasi ini diduga adalah yang terbaik, terutama di sekitar masjid. Hasil pengukuran geolistrik menunjukkan bahwa air tawar didapat sampai kedalaman 4 meter, sedangkan lapisan di bawahnya (pada kedalaman 7 meter) adalah payau sampai asin (Gambar 7). Gambar 8 menunjukkan visualisasi pseudo perpotongan lintasan 10-lintasan 11 dan lintasan 12-lintasan 13. Metode pengukuran geolistrik detail yang digunakan di lokasi ini sama dengan yang dilakukan di sekitar sumur injeksi SIMBAT.
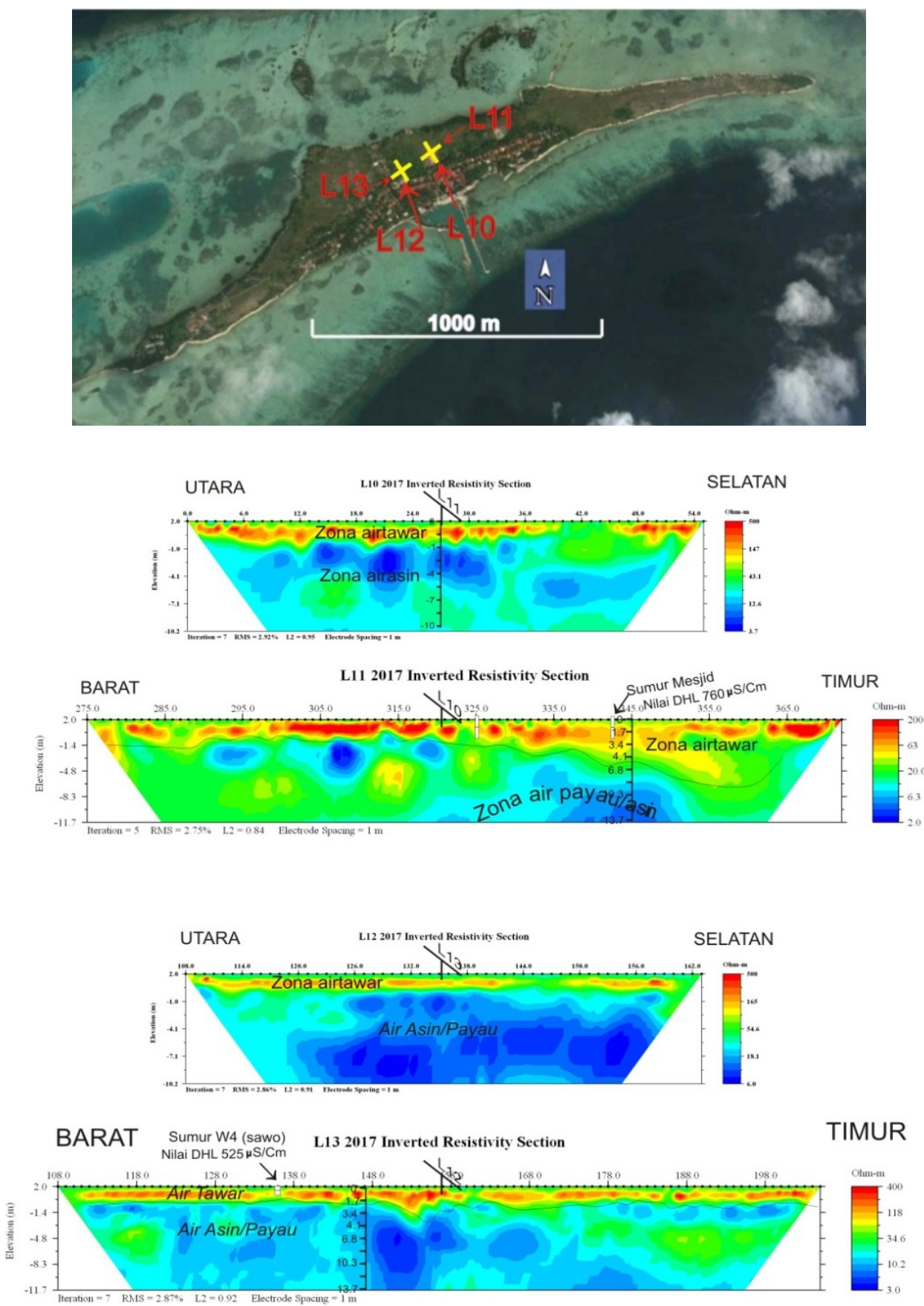

Gambar 7. Penampang Geolistrik di Sekitar Masjid dan Sumur Sawo (L10, L11, L12 dan L13) 

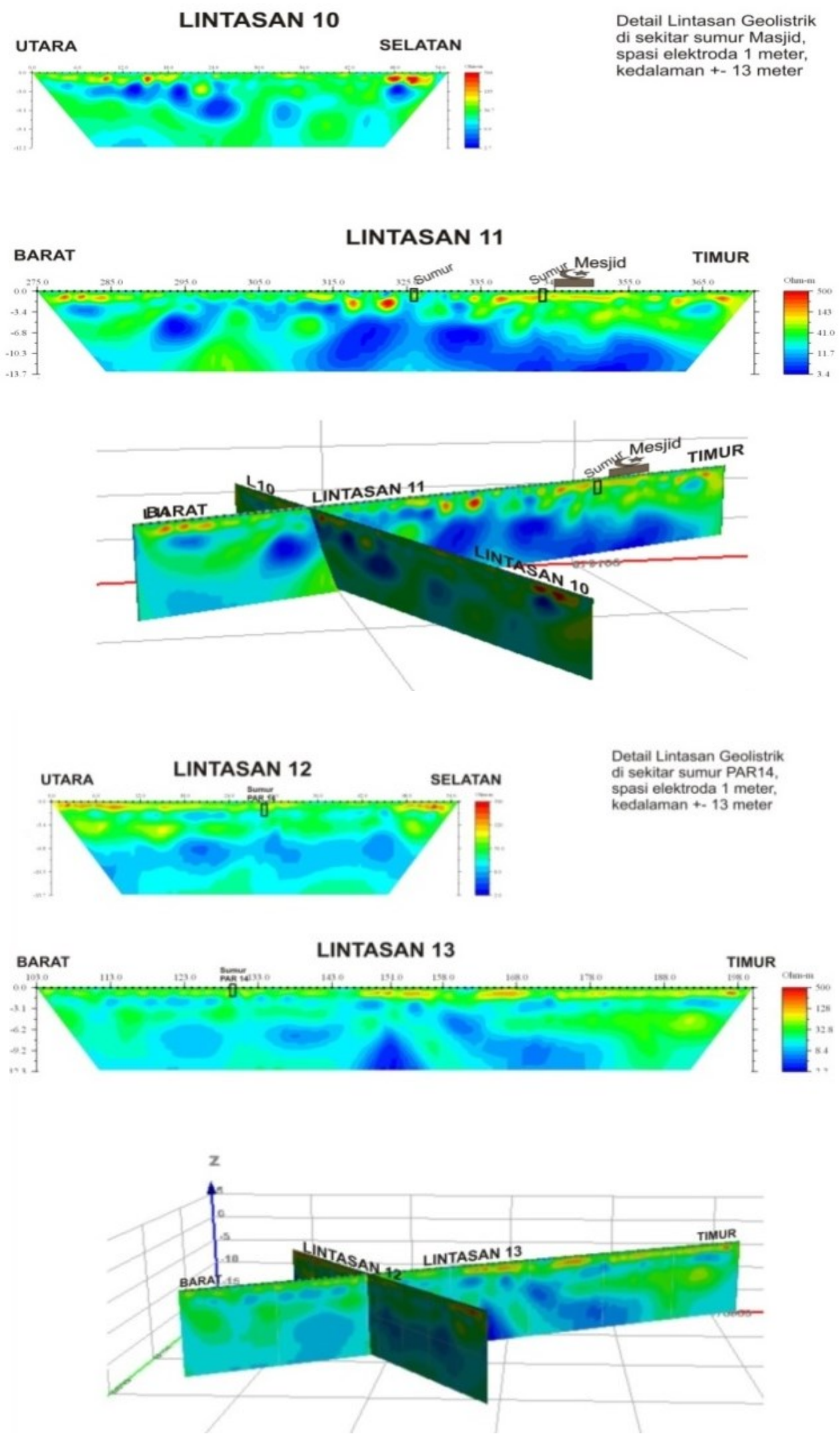

Gambar 8. Penampilan Pseudo Perpotongan Lintasan 10-Lintasan 11 dan Lintasan 12-Lintasan 13 
Lokasi pengukuran geolistrik selanjutnya adalah regional Pulau Pari. Pada pengukuran geolistrik di lokasi ini juga dilakukan sebanyak empat lintasan (lintasan 1,2,3, dan 4) (Gambar 9). Lintasan 1 arah memanjang pulau dan lintasan 2, 3, dan 4 arah melintang pulau. Lintasan 1 berada di tengah-tengah Pulau Pari dengan panjang lintasan sekitar 1,1 km. Lintasan ini dipilih karena sepanjang lintasan ini lebih banyak ditemukan air yang relatif lebih tawar dibandingkan dengan wilayah lain. Selain itu lintasan ini diharapkan dapat memberikan gambaran adanya sedimen pantai yang lebih tebal atau beachridge. Keberadaan sedimen tersebut akan mampu menyimpan air tawar lebih banyak atau mampu berfungsi sebagai akuifer dibandingkan dengan sedimen yang lebih tipis.
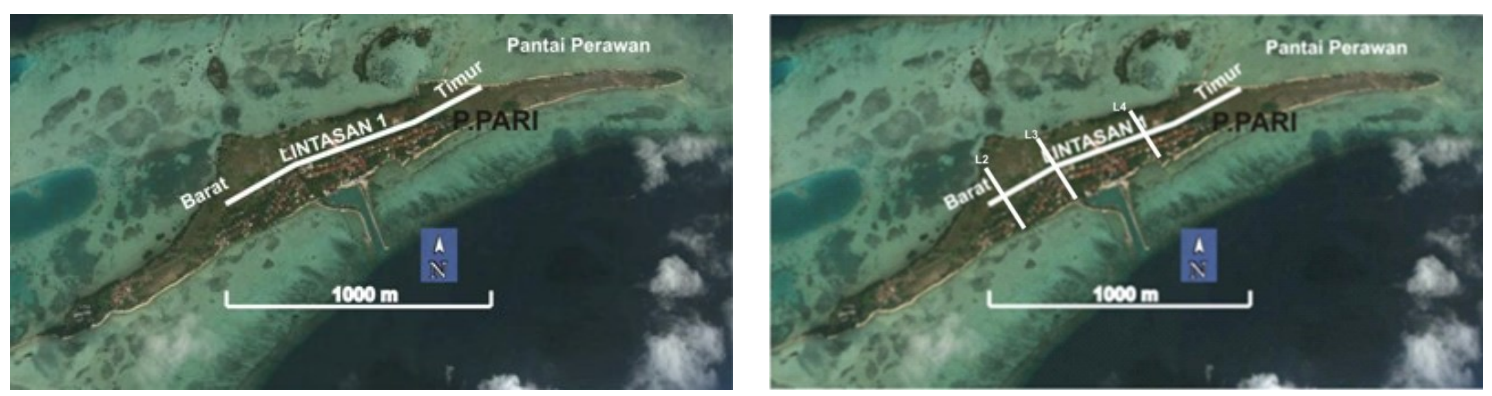

Gambar 9. Pengukuran Geolistrik Regional Pulau Pari pada Lintasan 1, 2, 3, dan 4

Gambar 10 adalah hasil interpretasi pengukuran geolistrik regional Pulau Pari. Sedangkan Gambar 11 adalah penampang hasil interpretasi pengukuran geolistrik untuk lintasan 2, 3, dan 4 yang dibandingkan dengan potongan segmen pada lintasan 1 . Hasil pengukuran geolistrik pada lokasi regional Pulau Pari ini menunjukkan bahwa air tanah Pulau Pari didominasi oleh air asin. Ini dicirikan oleh adanya akuifer dengan harga resistivitas besar, antara 30 sampai dengan 120 Ohm-m. Akuifer ini terdapat pada batuan pasir dan fragmen koral. Kedalaman akuifer rata-rata 7 meter yang terisi oleh air tawar sampai payau. Pada akuifer di sebelah barat pulau, potensi air tawar sangat tipis dengan kedalaman 0,5 m kemudian menebal ke bagaian tengah hingga kedalaman 4 meter, selanjutnya menipis kembali ke arah timur pulau hingga Pantai Perawan (lihat Gambar 7 dan Gambar 8).

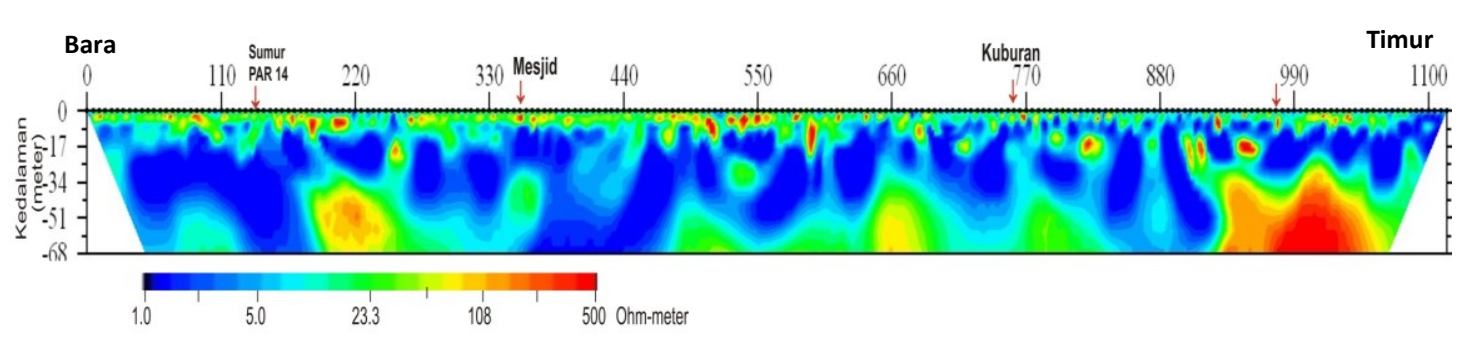

\section{Gambar 10. Interpretasi Hasil Pengukuran Geolistrik Lintasan 1 (Memanjang Pulau, Barat-Timur)}

Berdasarkan hasil pengukuran geolistrik di tiga lokasi tersebut di atas, kemudian dibuat skema (Gambar 10) untuk menentukan volume lensa air di Pulau Pari yang digunakan untuk memperkirakan kemampuan pulau dalam menampung air hujan. Panjang akuifer diperkirakan sebesar $1.500 \mathrm{~m}$ dan lebar akuifer rata-rata dari barat hingga ke timur adalah $150 \mathrm{~m}$. Dengan demikian luas permukaan akuifer dapat diperkirakan sebesar $225.000 \mathrm{~m}^{2}(1500 \mathrm{~m} \times 150 \mathrm{~m})$. Dari hasil interpretasi pengukuran geolistrik tersebut di atas, 


\section{Estimasi Daya Dukung Sumber Daya Air di Pulau Kecil (Studi Kasus Pulau Pari)}

diambil nilai kedalaman akuifer rata-rata untuk Pulau Pari adalah $3,26 \mathrm{~m} \approx 3 \mathrm{~m}$ (rata-rata dari $0,8 \mathrm{~d}, 4 \mathrm{~d}, 7 \mathrm{~d}, 4 \mathrm{~d}$, dan $0,5 \mathrm{~d}$ ) dengan kedalaman air tawar eksisting rata-rata 1 meter. Dengan demikian, berdasarkan data pengukuran golistrik dapat disimpulkan bahwa potensi penyimpanan akuifer Pulau Pari terhadap air hujan sebesar 675 ribu $\mathrm{m}^{3}$. Pada saat ini (kondisi eksisting) potensi ketersediaan air tawar di Pulau Pari berkisar 225 ribu m (berdasarkan hasil survei kedalaman air tawar rata-rata di Pulau Pari hanya 1 meter).
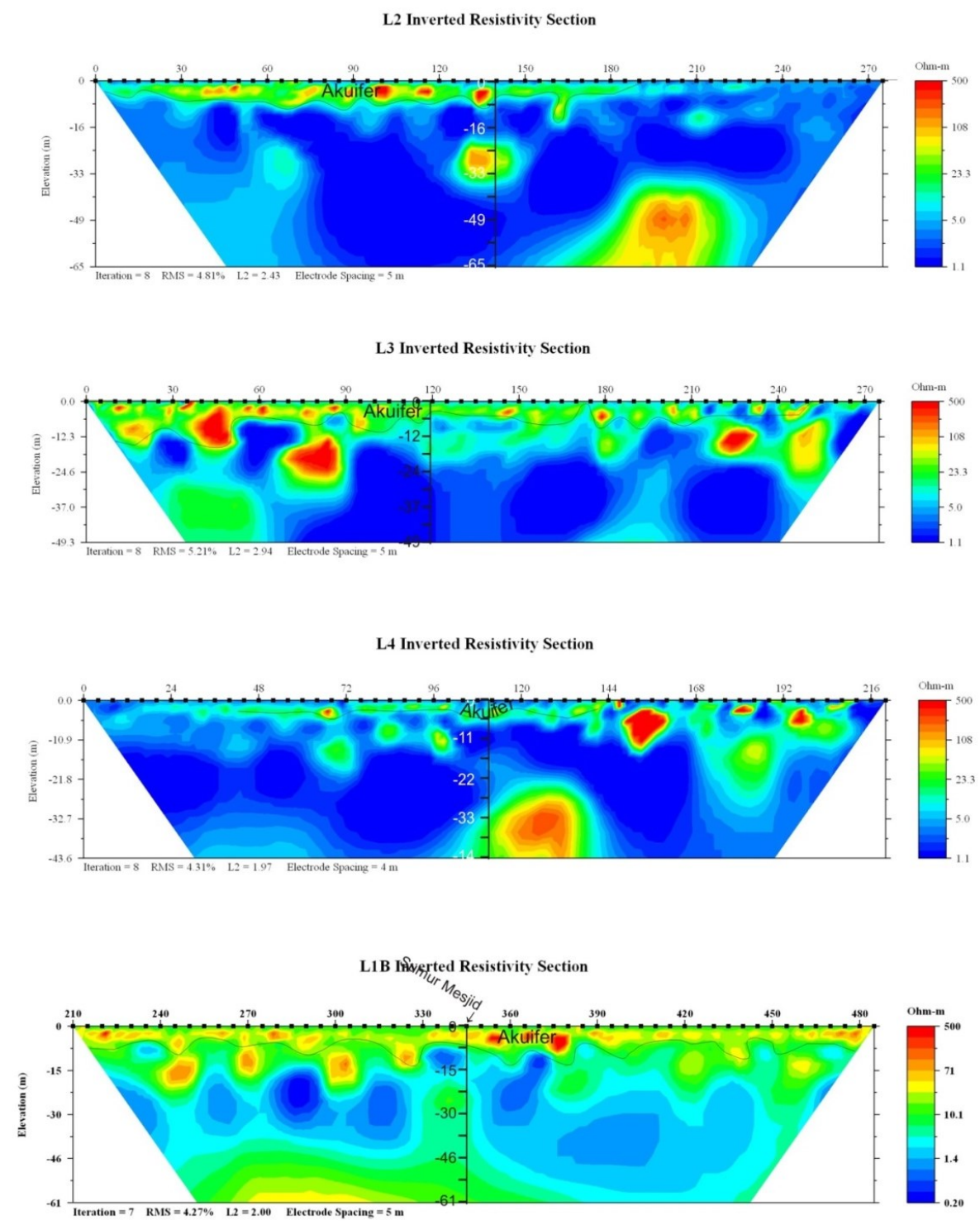

\section{Gambar 11. Penampang atau Visualisasi Hasil Interpretasi Pengukuran Geolistrik di Lintasan 2,3, dan 4 yang Dibandingkan dengan Segmen pada Lintasan 1}

\section{Hasil Uji Akuifer}

Uji ini dilakukan untuk mengetahui kemampuan tanah di Pulau Pari dalam meloloskan air (permeabilitas) sekaligus mengetahui kemampuan air mengalir di dalam tanah (konduktivitas hidraulis). Kemampuan tanah dalam menyimpan air di pulau kecil selain dipengaruhi oleh karakteristik tanah itu sendiri (internal) juga dipengaruhi oleh hujan dan pengaruh pasang surut (eksternal). 
Uji akuifer dilakukan pada tiga titik. Masing-masing titik yang dimaksud adalah titik F-1 berada di pantai barat pulau (disekitar lokasi kantor UPT LPKSDMO Pari), titik F-2 berada di dekat sumur pantau di permukiman penduduk yang posisinya mewakili titik tengah pulau, dan F-3 berada di pantai timur pulau (Pantai Perawan). Ketiga lokasi tersebut ditunjukkan pada Gambar 12.

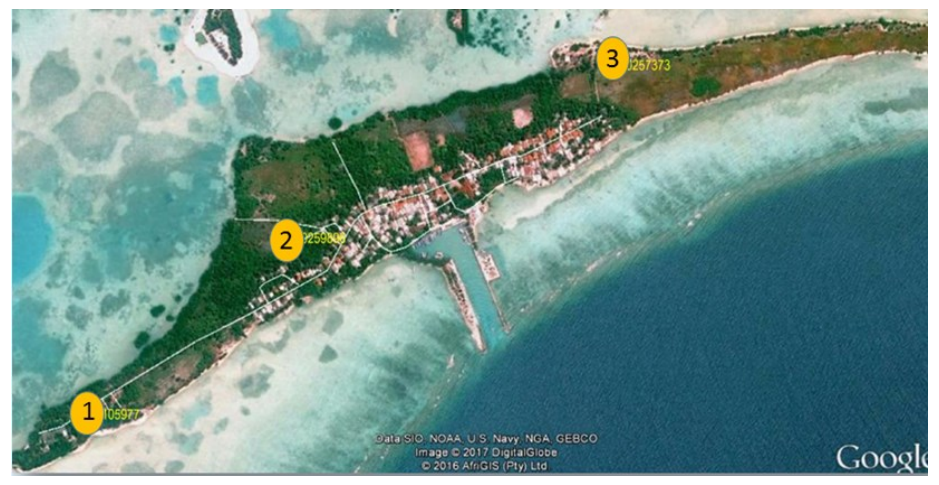

\section{Gambar 12. Titik Lokasi Uji Akuifer di Pulau Pari}

Gambar 13 adalah grafik hasil uji akuifer di titik F-1, (a) waktu surut dan (b) waktu pasang. Saat surut dilakukan dengan $t_{0}$ pukul 21.00 WIB dan delta $t$ selama 148 menit. Hasil pengujian memberikan nilai permeabilitas lapangan (flow rate) sebesar $0,0061 \mathrm{~cm}^{2} / \mathrm{dt}$ dan nilai laju infiltrasi $(\mathrm{K})$ sebesar 2,1667 $\mathrm{cm} / \mathrm{dt}$. Sementara pada kondisi pasang dilakukan dengan $t_{o}$ pukul 09.00 WIB dengan delta $t$ selama 148 menit. Hasil pengujian memberikan nilai permeabilitas lapangan sebesar $0,0151 \mathrm{~cm}^{2} / \mathrm{dt}$ dan nilai laju infiltrasi $(\mathrm{K})$ sebesar 2,500 $\mathrm{cm} / \mathrm{dt}$.

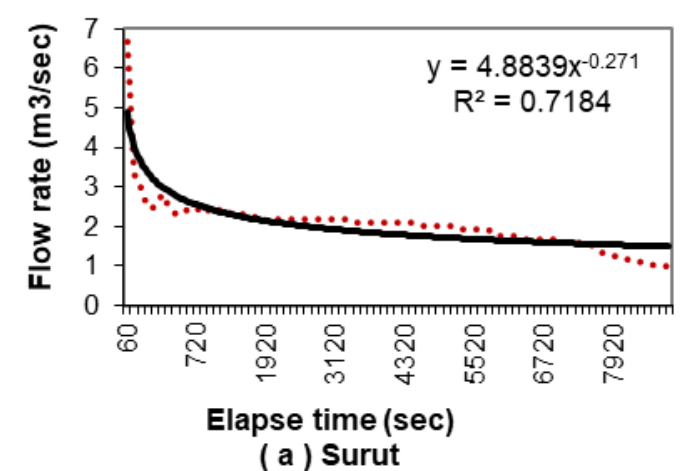

(a) Surut

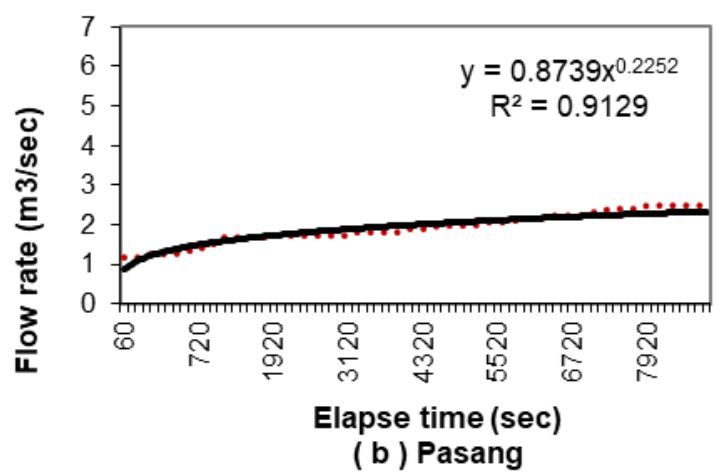

(b) Pasang

\section{Gambar 13. Hasil Uji Infiltrasi di Titik F-1}

Gambar 14 adalah grafik hasil uji akuifer di titik F-2, (a) waktu surut dan (b) waktu pasang. Seperti hal uji di titik F-1, kondisi surut dan pasang, masing-masing dilakukan pada $t_{o}$ pukul 21.00 WIB dan $t_{o}$ pukul 09.00 WIB. Delta t selama melakukan uji akuifer pada saat air laut surut maupun pasang dilakukan dengan waktu yang sama yaitu selama 132 menit untuk mencapai kondisi konstan. Hasil pengujian memberikan nilai permeabilitas lapangan sebesar $0,0151 \mathrm{~cm}^{2} / \mathrm{dt}$ dan $0,0368 \mathrm{~cm}^{2} / \mathrm{dt}$ masing-masing pada kondisi surut dan pasang. Sementara nilai laju infiltrasi $(\mathrm{K})$ sebesar $2,500 \mathrm{~cm} / \mathrm{dt}$ dan $6,0833 \mathrm{~cm} / \mathrm{dt}$ masing-masing pada kondisi surut dan pasang. 


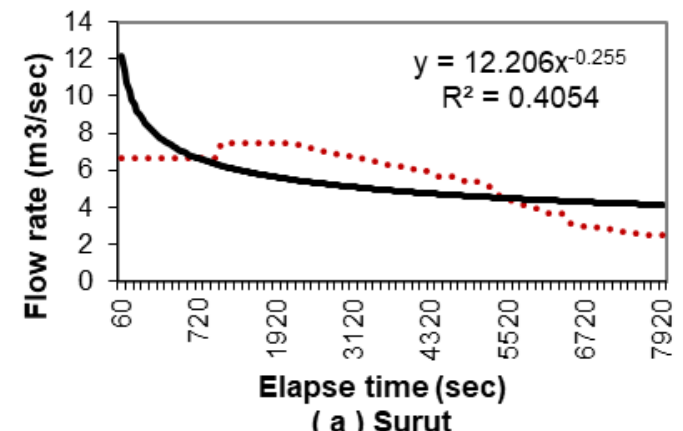

(a) Surut

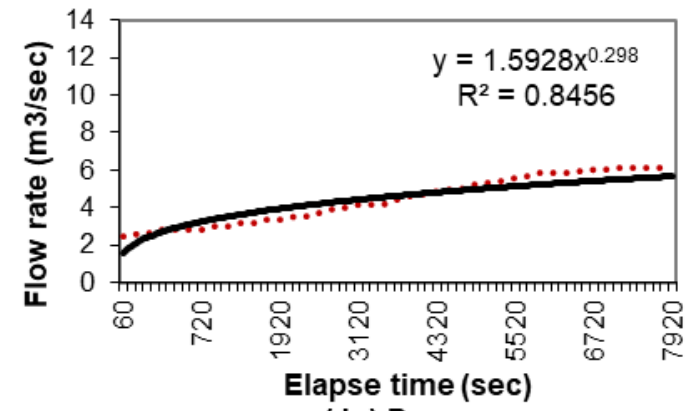

(b) Pasang

\section{Gambar 14. Hasil Uji Infiltrasi di Titik F-2}

Gambar 15 adalah grafik hasil uji infiltrasi di titik F-3, (a) waktu surut dan (b) waktu pasang. Seperti hal uji di titik F-1 dan F-2, uji akuifer di titik F-3 juga dilakukan pada dua waktu yang berbeda yaitu pada kondisi surut dan pasang, masing-masing dilakukan pada $t_{\circ}$ pukul 21.00 WIB dan to pukul 09.00 WIB. Delta t selama melakukan uji tersebut pada saat air laut surut maupun pasang dilakukan dengan waktu yang sama yaitu selama 120 menit untuk mencapai kondisi konstan. Hasil pengujian memberikan nilai permeabilitas lapangan sebesar $0,0161 \mathrm{~cm}^{2} / \mathrm{dt}$ dan $0,0353 \mathrm{~cm}^{2} / \mathrm{dt}$ masing-masing pada kondisi surut dan pasang. Sementara nilai laju infiltrasi $(\mathrm{K})$ sebesar $2,6667 \mathrm{~cm} / \mathrm{dt}$ dan $5,8333 \mathrm{~cm} / \mathrm{dt}$ masing-masing pada kondisi surut dan pasang. Tabel 2 adalah rangkuman hasil uji akuifer di tiga titik tersebut di atas.

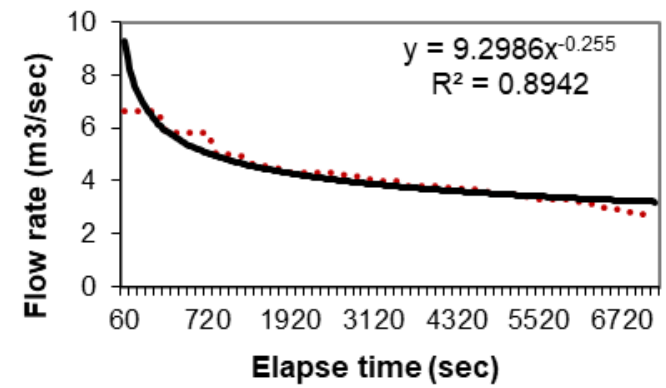

(a) Surut

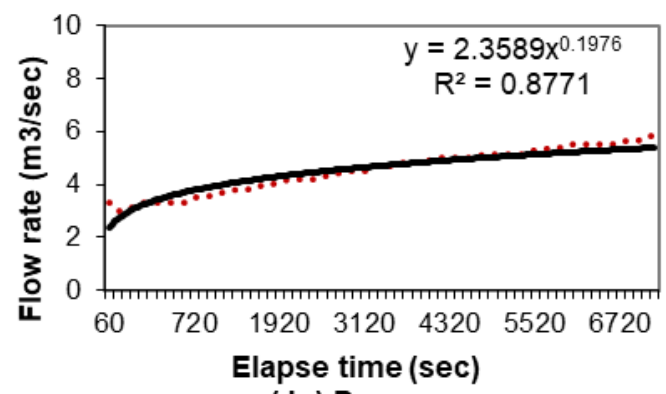

(b) Pasang

\section{Gambar 15. Hasil Uji Infiltrasi di Titik F-3}

Tabel 2. Rekapitulasi Hasil Uji Akuifer di Pulau Pari

\begin{tabular}{|c|c|c|c|c|c|}
\hline \multirow[b]{2}{*}{ Kode } & \multicolumn{2}{|c|}{$\begin{array}{l}\text { Laju Infiltrasi } \\
\text { K - cm/dt }\end{array}$} & \multicolumn{2}{|c|}{$\begin{array}{l}\text { Permeabilitas Lapangan } \\
\text { (flow rate })-\mathrm{cm}^{3} / \mathrm{dt}\end{array}$} & \multirow[b]{2}{*}{$\begin{array}{c}\text { Lokasi dan Penggunaan Lahan } \\
\text { di Sekitarnya }\end{array}$} \\
\hline & $\begin{array}{c}\text { Surut } \\
\text { pk:21.00 } \\
\text { WIB } \\
\end{array}$ & $\begin{array}{c}\text { Pasang } \\
\text { pk: 09.00 } \\
\text { WIB } \\
\end{array}$ & $\begin{array}{c}\text { Surut } \\
\text { pk:21.00 } \\
\text { WIB } \\
\end{array}$ & $\begin{array}{c}\text { Pasang } \\
\text { pk: } 09.00 \\
\text { WIB }\end{array}$ & \\
\hline F-1 & 1.00 & 2.5000 & 0.0061 & 0.0151 & \multirow{4}{*}{$\begin{array}{l}\text { Ruang terbuka di UPT LPK } \\
\text { SDMO P. Pari } \\
\text { Kebun, alang-alang di dekat W-4 } \\
\text { Alang-alang di Pantai Perawan di } \\
\text { sekitar W-10 }\end{array}$} \\
\hline F-2 & 2.50 & 6.0833 & 0.0151 & 0.0368 & \\
\hline F-3 & 2.67 & 5.8333 & 0.0161 & 0.0353 & \\
\hline $\begin{array}{l}\text { Rata- } \\
\text { rata }\end{array}$ & 2.06 & 4.81 & 0.0124 & 0.0291 & \\
\hline
\end{tabular}




\begin{tabular}{|c|c|c|c|c|c|}
\hline \multirow[b]{2}{*}{ Kode } & \multicolumn{2}{|c|}{$\begin{array}{l}\text { Laju Infiltrasi } \\
\text { K - cm/dt }\end{array}$} & \multicolumn{2}{|c|}{$\begin{array}{l}\text { Permeabilitas Lapangan } \\
\text { (flow rate) }-\mathrm{cm}^{3} / \mathrm{dt}\end{array}$} & \multirow[b]{2}{*}{$\begin{array}{c}\text { Lokasi dan Penggunaan Lahan } \\
\text { di Sekitarnya }\end{array}$} \\
\hline & $\begin{array}{c}\text { Surut } \\
\text { pk:21.00 } \\
\text { WIB }\end{array}$ & $\begin{array}{c}\text { Pasang } \\
\text { pk: 09.00 } \\
\text { WIB }\end{array}$ & $\begin{array}{c}\text { Surut } \\
\text { pk:21.00 } \\
\text { WIB }\end{array}$ & $\begin{array}{c}\text { Pasang } \\
\text { pk: 09.00 } \\
\text { WIB }\end{array}$ & \\
\hline $\begin{array}{l}\text { Rata- } \\
\text { rata }\end{array}$ & \multicolumn{2}{|c|}{3.43} & \multicolumn{2}{|c|}{0.0208} & \\
\hline
\end{tabular}

Sumber: Analisis Penulis, 2017

\section{Perhitungan Estimasi Daya Dukung Sumber Daya Air di Pulau Pari}

Analisis daya dukung pada penelitian ini dibatasi pada aspek kuantitas, yang didasarkan pada perhitungan keseimbangan antara ketersediaan dan kebutuhan air tawar. Berdasarkan hasil perhitungan pada Tabel 1, maka sangat tidak mungkin apabila ketersediaan air tawar di Pulau Pari hanya menggantungkan pada air hujan sepanjang tahun secara alami karena air hujan yang jatuh akan menguap kembali melalui proses evapotranspirasi. Oleh karena itu, sesuai dengan potensi dan keterbatasan Pulau Pari, maka ada dua alternatif yang bisa dilakukan yaitu menerapkan teknologi $\mathrm{PAH}$ karena curah hujannya yang tinggi, dan/atau sumur imbuhan karena kecepatan infiltrasi tanahnya yang sangat tinggi.

Berdasarkan nilai laju infiltrasi sebesar $3,43 \mathrm{~cm} /$ detik atau $2,06 \mathrm{~m} / \mathrm{menit}$ dan ketebalan akuifer $3 \mathrm{~m}$, maka daya imbuh tanah di Pulau Pari rata-rata sebesar 2,8 m/menit. Sementara volume yang diimbuhkan berdasarkan data hujan $(2.219 \mathrm{~mm} / \mathrm{tahun})$ dan luas daerah tangkapan $41.32 \mathrm{Ha}$ adalah sebesar $0,17 \mathrm{~mm} / \mathrm{menit}$. Berdasarkan rasio volume yang diimbuhkan dengan daya imbuh tanah tersebut, maka semua air hujan yang jatuh akan meresap ke dalam tanah. Ini dibuktikan dengan air hujan yang jatuh dan menggenang di sekitar UPT LPKSDMO Pulau Pari, tidak lama setelah hujan berhenti air genangan langsung habis meresap ke dalam tanah. Dengan demikian, kapasitas air yang dapat disimpan dalam tanah adalah volume air hujan dan pembatasnya adalah kapasitas atau volume lensa air di Pulau Pari yaitu 225 ribu sampai dengan 675 ribu m³.

Adapun kebutuhan air diperkirakan dari jumlah penduduk dan pendatang (wisatawan) Pulau Pari. Data Kelurahan Pulau Pari per Februari 2016 menunjukkan bahwa jumlah penduduk yang tinggal di Pulau Pari sebanyak 1.041 jiwa. Kemudian data tersebut meningkat pada Desember 2016 menjadi 1.200 jiwa menurut catatan di RW 11 Kelurahan Pulau Pari. Dengan demikian, ada peningkatan jumlah penduduk rata-rata 19 jiwa tiap bulan atau 228 jiwa tiap tahun. Jumlah pengunjung yang tercatat di UPT LPKSDMO Pulau Pari tercatat sebanyak 3.811 orang. Menurut pihak pengelola mess UPT tersebut ada kecenderungan peningkatan jumlah pengunjung tiap tahun. Hal ini terlihat dengan banyaknya rumah penduduk yang berkembang menjadi homestay. Berdasarkan data tahun 2016, maka jumlah penduduk ditambah dengan pengunjung sebanyak 5.011 orang. Apabila kebutuhan air mengacu pada basic need kriteria WHO (60 L/orang/hari), maka jumlah kebutuhan air tawar masyarakat yang tinggal di Pulau Pari adalah sebesar 26.280 $\mathrm{m}^{3} /$ tahun. Dengan adanya penambahan jumlah pengunjung sesuai data dari UPT LPKSDMO Pulau Pari, maka total kebutuhan air tawar yang perlu disediakan sebesar $109.741 \mathrm{~m}^{3} /$ tahun.

Dengan demikian, apabila tanpa aplikasi teknologi atau dengan kata lain membiarkan air hujan meresap ke dalam tanah secara alami, maka status daya dukung sumber daya air di Pulau Pari adalah 2,05 yang artinya aman (Tabel 3). Status ini belum mempertimbangkan kualitas air yang tersedia. Hasil survei lapangan menunjukkan bahwa air sumur yang digunakan oleh masyarakat Pulau Pari tidak semuanya tawar, dengan kondisi air tawar memiliki nilai DHL < $1500 \mu \mathrm{S} / \mathrm{cm}$ (Gambar 16). Hasil pemeriksaan nilai Fecal coliform juga menunjukkan bahwa air sumur yang disurvei secara umum tercemar oleh kotoran hewan atau manusia dengan nilai jumlah Fecal coliform lebih 100 dalam $100 \mathrm{~mL}$ contoh (Tabel 4). 
Berdasarkan hasil perhitungan (Tabel 3) dan analisis data yang ditunjukkan pada Gambar 16 dan Tabel 4, maka daya dukung sumber daya air di Pulau Pari dalam status "warning". Ketersediaan air dari aspek kuantitas terpenuhi namun aspek kualitasnya tidak sesuai dengan peruntukannya yaitu untuk memenuhi kebutuhan air baku air minum bagi masyarakat Pulau Pari. Nilai DHL yang tinggi dan jumlah Fecal coliform yang tidak memenuhi standar kesehatan merupakan indikasi bahwa ketersediaan air tanah di Pulau Pari terancam karena intrusi air laut dan pencemaran dari limbah rumah tangga atau sanitasi yang kurang baik. Oleh karena itu, berdasarkan potensi curah hujan yang ada di Pulau Pari, maka aplikasi teknologi PAH merupakan usaha alternatif untuk mengatasi kelangkaan air tawar di Pulau Pari. Selain potensinya yang signifikan, kualitasnya juga relatif lebih baik daripada air tanah yang ada di Pulau Pari (Bailey et al, 2018).

\section{Tabel 3. Hasil Analisis Status Daya Dukung Sumber Daya Air di Pulau Pari Tanpa Intervensi Teknologi}

\begin{tabular}{lccc}
\hline \multicolumn{1}{c}{ Keterangan } & $\begin{array}{c}\text { Ketersediaan } \\
\left(\mathbf{m}^{\mathbf{3}} / \text { tahun }\right)\end{array}$ & $\begin{array}{c}\text { Kebutuhan } \\
\left(\mathbf{m}^{\mathbf{3}} / \text { tahun }\right)\end{array}$ & $\begin{array}{c}\text { Status Daya Dukung } \\
(\text { ketersediaan/kebutuhan) }\end{array}$ \\
\hline Imbuhan alami sesuai dengan & 225.000 & 109.741 & $\approx 2,05$ \\
kapasitas daya tampung & & & $($ Aman $)$ \\
Pulau Pari (kondisi eksisting) & & &
\end{tabular}

Sumber: Analisis Penulis, 2018
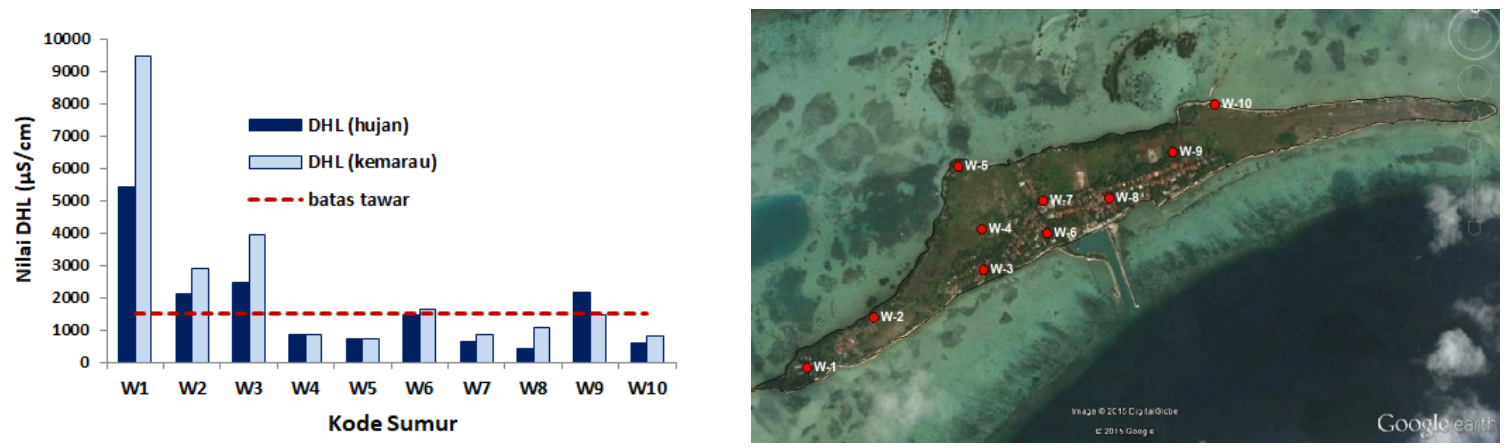

Gambar 16. Hasil Pemeriksaan Nilai DHL Sumur Pantau di Pulau Pari

Tabel 4. Hasil Pemeriksaan Fecal ColiformSumur Pantau di Pulau Pari

\begin{tabular}{ccccc}
\hline \multirow{2}{*}{ Kode Sumur } & \multicolumn{2}{c}{ Hujan } & \multicolumn{2}{c}{ Kemarau } \\
\cline { 2 - 5 } & Pasang & Surut & Pasang & Surut \\
\hline W1 & $\geq 2400$ & 460 & 43 & $\geq 2400$ \\
W2 & $\geq 2400$ & 1100 & 21 & $\geq 2400$ \\
W3 & $\geq 2400$ & 460 & 0 & 4 \\
W4 & $\geq 2400$ & $\geq 2400$ & 21 & $\geq 2400$ \\
W5 & $\geq 2400$ & 0 & $\geq 2400$ & 240 \\
W6 & 1100 & 1100 & $\geq 2400$ & 43 \\
W7 & $\geq 2400$ & 1100 & 4 & 1100 \\
W8 & 1100 & 23 & 1100 & 1100 \\
W9 & $\geq 2400$ & $\geq 2400$ & 4 & $\geq 2400$ \\
W10 & $\geq 2400$ & $\geq 2400$ & $\geq 2400$ \\
\hline
\end{tabular}

Sumber: Hasil Survei Lapangan Maret dan November, 2016

Dengan asumsi bahwa sesuai dengan Perda DKI Jakarta Tahun 2012, maka 40\% luas Pulau Pari digunakan sebagai permukiman, sedangkan hasil survei lapangan pada tahun 2017 menunjukkan bahwa luas permukiman di Pulau Pari baru mencapai 20\%-nya. 
Berdasarkan data dan asumsi tersebut, maka volume air hujan yang dapat ditangkap dan disimpan adalah sebesar:

$$
\begin{aligned}
\mathrm{HW} & =2.219 \mathrm{~mm} / \mathrm{th} \times(41,32 \mathrm{Ha} \times 20 \%) \times 80 \% \\
& \approx 146.721\left(\mathrm{~m}^{3} / \text { tahun }\right)
\end{aligned}
$$

Dengan demikian, apabila ketersediaan air dapat dipenuhi dari air hujan sebesar $146.721 \mathrm{~m}^{3} /$ tahun, maka status daya dukung sumber daya air di Pulau Pari eksisiting ditunjukkan pada Tabel 5. Sementara itu, perkiraan tahun 2025 diasumsikan bahwa alokasi lahan untuk permukiman telah tercapai sebesar $40 \%$ dari luas total Pulau Pari. Pada tahun tersebut juga dikeluarkan kebijakan bahwa semua rumah dan gedung wajib menerapkan teknologi PAH. Dengan asumsi semua penduduk telah melakukan pemanenan air hujan, maka total ketersediaan air dengan kualitas yang lebih baik sebanyak $293.443 \mathrm{~m}^{3} /$ tahun (asumsi bahwa 40\% luas Pulau Pari merupakan luas tangkapan air hujan).

Tabel 5. Hasil Analisis Status Daya Dukung Sumber Daya Air di Pulau Pari

\begin{tabular}{lccc}
\hline \multicolumn{1}{c}{ Keterangan } & $\begin{array}{c}\text { Ketersediaan } \\
\left(\mathbf{m}^{\mathbf{3}} / \mathbf{t a h u n}\right)\end{array}$ & $\begin{array}{c}\text { Kebutuhan } \\
\left(\mathbf{m}^{\mathbf{3}} / \mathbf{t a h u n}\right)\end{array}$ & $\begin{array}{c}\text { Status Daya Dukung } \\
(\text { ketersediaan/kebutuhan) }\end{array}$ \\
$\begin{array}{l}\text { Menggunakan teknologi PAH } \\
\text { (luas tangkapan 20\%, kondisi }\end{array}$ & 146.721 & 109.741 & $\approx 1,34$ \\
eksisting) & & & (Aman Bersyarat) \\
\hline
\end{tabular}

Sumber: Analisis Penulis, 2018

Jumlah kebutuhan diperkirakan juga akan meningkat pada tahun 2025. Berdasarkan laju kenaikan penduduk eksisting, maka pada tahun 2025 diperkirakan jumlah penduduk Pulau Pari meningkat menjadi 3.209 jiwa dan asumsi kenaikan wisatawan sebesar $5 \%$. Dari data tersebut dapat ditentukan status daya dukung sumber daya air di Pulau Pari pada tahun 2025 sebagaimana ditampilkan pada Tabel 6 .

Tabel 6. Hasil Analisis Status Daya Dukung Sumber Daya Air di Pulau Pari Perkiraan Tahun 2025

\begin{tabular}{lccc}
\hline \multicolumn{1}{c}{ Keterangan } & $\begin{array}{c}\text { Ketersediaan } \\
\left(\mathbf{m}^{\mathbf{3}} / \mathbf{t a h u n}\right)\end{array}$ & $\begin{array}{c}\text { Kebutuhan } \\
\left(\mathbf{m}^{\mathbf{3}} / \mathbf{t a h u n}\right)\end{array}$ & $\begin{array}{c}\text { Status Daya Dukung } \\
(\text { ketersediaan/kebutuhan })\end{array}$ \\
\hline $\begin{array}{l}\text { Menggunakan teknologi PAH } \\
\text { (luas tangkapan 40\%, semua } \\
\text { lahan permukinan digunakan } \\
\text { secara penuh) }\end{array}$ & 293.443 & 199.748 & $\begin{array}{c}\approx 1,47 \\
\text { (Aman Bersyarat) }\end{array}$ \\
\hline Sumber Analisis Penulis, 2018 & & &
\end{tabular}

Hasil perhitungan pada Tabel 5 ataupun Tabel 6 menunjukkan bahwa sebenarnya dengan teknologi PAH ketersediaan air di Pulau Pari masih dapat memenuhi kebutuhan dasar masyarakat Pulau Pari maupun pengunjung. Sementara untuk memenuhi kebutuhan lainnya, seperti mencuci baju, menyiram tanaman, dan lain-lain bisa dipenuhi dari air tanah. Selain itu, persyaratan yang perlu dilakukan, khususnya oleh pemangku kepentingan, adalah melakukan pengelolaan pengunjung atau kunjungan wisata ke Pulau Pari. Penetapan Pulau Pari sebagai tujuan wisata sangat perlu memperhatikan ketersediaan air yang ada di pulau. Pengaturan dan pembatasan kunjungan tersebut diperlukan untuk menghindari defisit air tawar. Kondisi defisit air ini akan berdampak pada kelangsungan hidup masyarakat yang tinggal di Pulau Pari dan ekosistemnya.

\section{Kesimpulan}

Ketersediaan air tawar di Pulau Pari sangat terbatas karena bergantung pada lensa air tawar. Tipikal lensa air tawar di pulau kecil umumnya dipengaruhi beberapa faktor utama, 
yaitu luas tangkapan air hujan, jenis akuifer pulau, iklim, dan aktivitas masyarakat setempat. Luas tangkapan air hujan merupakan faktor pembatas alami yang bersifat internal. Pulau Pari hanya memiliki luas tangkapan air hujan sebesar 41,32 ha. Luasan ini memang sangat kecil sehingga Pulau Pari dikategorikan sebagai tiny island (pulau sangat kecil). Faktor akuifer pulau ini juga merupakan faktor internal yang bergantung pada jenis geologi dan tanah. Berdasarkan hasil pengukuran geolistrik dan uji akuifer di Pulau Pari, kapasitas maksimum lensa air tawar di Pulau Pari adalah $675.000 \mathrm{~m}^{3}$ dengan kondisi eksisting (tahun 2016) sebesar $225.000 \mathrm{~m}^{3}$. Faktor iklim merupakan faktor eksternal yang tidak dapat dihindari namun bisa dkendalikan dan dikelola. Faktor iklim yang diperhitungkan dalam studi ini adalah curah hujan dan temperatur udara. Meskipun curah hujan di Pulau Pari relatif tinggi $(2.219 \mathrm{~mm} /$ tahun) namun evapotranspirasi di lokasi ini juga tinggi. Berdasarkan hasil perhitungan keseimbangan air, air yang dapat disimpan sebagai air tanah hanya $38 \mathrm{~mm} /$ tahun. Dengan nilai simpanan air tanah sebesar 38 $\mathrm{mm} /$ tahun, hasil estimasi daya dukung masih menunjukkan kondisi aman (supply/demand 2,05). Namun nilai daya dukung tersebut belum memperhatikan aspek kualitas air (hanya perhitungan kuantitas atau volume air saja). Hasil analisis kualitas air di Pulau Pari menunjukkan adanya kontaminasi oleh aktivitas domestik (rumah tangga) dan intrusi air laut. Kondisi ini ditunjukkan berdasarkan hasil survei terhadap sumur-sumur penduduk di Pulau Pari yang masih menunjukkan keberadaan Fecal coliform lebih 100 dalam 100 mL contoh dan nilai DHL di atas $1.500 \mu \mathrm{S} / \mathrm{cm}$. Dengan demikian, apabila estimasi daya dukung sumber daya air didasarkan atas aspek kuantitas dan kualitas air, maka kondisi sumber daya air di Pulau Pari sangat rentan. Rekomendasi yang dapat diberikan adalah menerapkan teknologi pemanenan air hujan mengingat curah hujan di lokasi ini sangat tinggi. Selain kualitasnya yang relatif lebih baik dari air tanah, hasil perhitungan juga menunjukkan bahwa pemanenan air hujan di Pulau Pari masih dapat memenuhi kebutuhan dasar masyarakat Pulau Pari dan pengunjung (wisatawan). Hasil perhitungan estimasi nilai daya dukung dengan teknologi ini adalah aman bersyarat (1,34 sampai 1,47). Persyaratan utama yang wajib dipenuhi adalah melakukan pengelolaan pariwisata sehingga jumlah pengunjung Pulau Pari tetap dapat terkontrol dan tidak melebihi daya dukung sumber daya airnya.

\section{Ucapan Terima Kasih}

Penulis mengucapkan terima kasih kepada LIPI yang telah membiayai kegiatan penelitian ini melalui Program Kegiatan Unggulan LIPI TA 2015-2017. Penulis juga mengucapkan terima kasih kepada semua anggota tim yang tergabung dalam kegiatan SIMBAT, khususnya (alm) Prof. Edi Prasetyo Utomo, Anna F.R, Ananta P, Arief R, dan Widya N. Tidak lupa penulis mengucapkan terima kasih kepada seluruh staf UPT LPKSDMO Pulau Pari dan warga RW 11 Kelurahan Pulau Pari atas bantuan dan partisipasinya dalam pelaksanaan kegiatan penelitian ini.

\section{Daftar Pustaka}

Advances Geosciences Inc (AGI). (2007). Instruction manual for earth imager $2 D$ version 2.2.2, resistivity and IP inversion software. Austin, Texas: Advanced Geosciences Inc.

Aunillah, H. N., Purwanto, P., \& Sugianto, D. N. (2014). Pola arus di perairan Pulau Pari Kepulauan Seribu DKI Jakarta. Jurnal Oseanogfrafi, 3(4), 642-650. Retrieved from https://ejournal3.undip.ac.id/index.php/joce/article/view/6940/6664.

Bailey, R. T., Beikmann, A., Kottermair, M., Taboroši, D., \& Jenson, J. W. (2018). Sustainability of rainwater Catchment Systems for Small Island Communities. Journal of Hydrology, 557, 137-146. doi:10.1016/j.jhydrol.2017.12.016. 
Bailey, R. T., Jenson, J. W., \& Olsen, A. E. (2010). Estimating the ground water resources of Atoll Islands. Water, 2, 1-27. doi:10.3390/w2010001.

Bailey, R. T., Khalil, A., \& Chatikavanij, V. (2014). Estimating current and future groundwater resources of the Maldives. Journal of The American Water Resources Asociation, 51(1), 112-122. doi:10.1111/jawr.12236.

Falkland, A. C. (1992). Investigation and monitoring of fresh-water lens behaviour on coral atolls (INT-88-R41). United Nations Department of Economic and Social Development.

Gregory, J. H., Michael, D. D., Miller, G. L., \& Jones, P. H. (2005). Analysis of double-ring infiltration techniques and development of a simple automatic water delivery system. Applied Turfgrass Science. doi:10.1094/ATS-2005-0531-01-MG.

Hidayah, Z., Rosyid, D. M., \& Dwito, H. (2016). Planning for sustainable small island management: Case study of Gili Timur Island East Java Province Indonesia. In Procedia - Social and Behavioral Sciences (Vol. 227, pp. 785-790). The Author(s). doi:10.1016/j.sbspro.2016.06.146.

Kartodihardjo, H. (2011). Konsep daya dukung dan daya tampung lingkungan hidup dalam kerangka perlindungan dan pengelolaan lingkungan hidup.

Loke, M. H. (2006). RES2DINV ver. 3.55. rapid $2 D$ resistivity \& IP inversion using the least squares method (Software manual).

Marganingrum, D. (2013). Manajemen sumberdaya air terpadu “Waduk Saguling” dalam rangka pengembangan SPAM regional KSN Cekungan Bandung. Institut Teknologi Bandung.

Marganingrum, D. (2018). Carrying capacity of water resources in Bandung Basin. IOP Conference Series: Earth and Environmental Science, 118. doi:10.1088/1755-1315/118/1/012026.

Masterson, J. P., Fienen, M. N., Thieler, E. R., Gesch, D. B., Gutierrez, B. T., \& Plant, N. G. (2013). Effects of sealevel rise on barrier island groundwater system dynamics - ecohydrological implications. Ecohydrology, 7, 1064-1071. doi:10.1002/eco.1442.

Narulita, I., Santoso, H., Hantoro, W. S., \& Djuwansah, R. (2005). Pengaruh pasang surut laut terhadap posisi kualitas air tanah di Pulau Pari, Kepulauan Seribu, DKI Jakarta. In Sumberdaya Air di Pulau Kecil Perairan Indonesia (pp. 64-79). Bandung: LIPI Press.

Parasnis, D. S. (1986). Principles of applied geophysics. United States: Chapman and Hall.

Post, V. E. A., Bosserelle, A. L., Galvis, S. C., Sinclair, P. J., \& Werner, A. D. (2018). On the resilience of smallisland freshwater lenses: Evidence of the long-term impacts of groundwater abstraction on Bonriki Island, Kiribati Vincent. Journal of Hydrology, 564, 133-148. doi:10.1016/j.jhydrol.2018.06.015.

Rasmussen, P., Sonnenborg, T. O., Goncear, G., \& Hinsby, K. (2013). Assessing impacts of climate change, sea level rise, and drainage canals on saltwater intrusion to coastal aquifer. Hydrology and Earth System Sciences, 17, 421-443. doi:10.5194/hess-17-421-2013.

Suparyanto, I. H. (2005). Sumberdaya air bagi pariwisata di Pulau Kecil. In Sumberdaya Air di Wilayah Pesisir dan Pulau-Pulau Kecil di Indonesia (pp. 85-101). Bandung: LIPI Press.

Tatas, T., Budipriyanto, A., Khoiri, M., Lestari, W., \& Rahman, A. (2015). Study on water balance in Poteran - a small island in East Java, Indonesia. Procedia Engineering, 125, 236-242. doi:10.1016/j.proeng.2015.11.034.

Traboulsi, H., \& Traboulsi, M. (2017). Rooftop level rainwater harvesting system. Applied Water Science, 72), 769-775. doi:10.1007/s13201-015-0289-8.

United Nations Environment Programme (UNEP). (2014). Emerging issues for small island developing states: Results of the UNEP/UNDESA foresight process. Nairobi, Kenya.

Utomo, E. P., Marganingrum, D., Sudrajat, Y., Rachmat, A., \& Ningrum, W. (2017). Rancang bangun pengelolaan sumberdaya air tanah untuk pengurangan risiko kekeringan akibat peningkatan cuaca ekstrim (perubahan iklim) di Pulau-Pulau Kecil. Bandung.

Utomo, E. P., Santoso, H., Kesumadharma, S., Sasmito, A., Rusydi, A. F., Purwoarminto, A., \& Ningrum, W. (2015). Rancang Bangun Pengelolaan Sumberdaya Airtanah Untuk Pengurangan Risiko Kekeringan Akibat Peningkatan Cuaca Ekstrim (Perubahan Iklim) Di Pulau-Pulau Kecil (Laporan Akhir TahunKegiatan Unggulan LIPI Tahun 2015). Bandung.

White, I., Falkland, T., Metutera, T., Metai, E., Overmars, M., Perez, P., \& Dray, A. (2007). Climatic and human influences on groundwater in Low Atolls. Vadose Zone Journal, 6(3), 581-590. doi:10.2136/vzj2006.0092. 